Web-Based Job Training Report Guidance System at SMKN 2 Kraksaan

\title{
Sistem Bimbingan Laporan Praktik Kerja Lapangan di SMKN 2 Kraksaan Berbasis Web
}

\author{
Matlubul Khairi \\ ${ }^{1}$ Dosen Program Studi Teknik Informatika, Universitas Nurul Jadid
}

INFORMASI ARTIKEL

Riwayat Artikel:

Dikirimkan 06 Januari 2020,

Direvisi 07 Januari 2020,

Diterima 08 Januari 2020.

\section{Kata Kunci:}

Sistem,

Bimbingan Laporan,

PKL,

Berbasis Web.

\section{Penulis Korespondensi:}

Matlubul Khairi,

Teknik Informatika,

Universitas Nurul Jadid

Paiton, Probolinggo, Indonesia.

Sangrato88@gmail.com

\begin{abstract}
ABSTRAK
Implementation of Field Work Practices (PKL) is an effort that can be made by SMK to continue to produce graduates who can compete in the business world and the industrial world (DU / DI). The government policy regarding learning at / from home during the Coronavirus Disease 2019 (COVID-19) pandemic has an impact on the reporting process at SMKN 2 Kraksaan. This study aims to build a report guidance system using server side-based web technology. This system was built using a waterfall model and PHP (PHP Hypertext Prepocessor) programming. System design tools used are Flowmap Diagrams, Data Flow Diagrams, and Entity Relationship Diagrams. The black box test results show that the output of the system is in line with expectations. User response to the system using a questionnaire resulted in a feasibility percentage of $83.6 \%$ with a very feasible category interpretation. It can be concluded from the test results that the Field Work Practices report guidance system is in accordance with user needs and is very suitable for use.

Penyelenggaraan Praktek kerja Lapangan(PKL) merupakan upaya yang dapat dilakukan SMK untuk tetap menghasilkan lulusan yang dapat bersaing di dunia usaha dan dunia industri (DU/DI). Kebijakan pemerintah tentang pembelajaran di/dari rumah pada masa pandemik Coronavirus Disease 2019 (COVID-19) memberikan dampak terhadap proses pembimbingan laporan di SMKN 2 Kraksaan. Penelitian ini bertujuan untuk membangun sistem bimbingan laporan PKL menggunakan teknologi web berbasis server side. Sistem ini dibangun menggunakan model waterfall dan pemrograman PHP (PHP Hypertext Prepocessor). Alat perancangan sistem yang digunakan adalah Flowmap Diagram, Data Flow Diagram, dan Entity Relationship Diagram. Hasil pengujian black box menunjukkan bahwa keluaran dari sistem sesuai dengan harapan. Respon pengguna terhadap sistem dengan menggunakan angket menghasilkan persentase kelayakan 83,6\% dengan interpretasi kategori sangat layak. Dapat disimpulkan dari hasil pengujian bahwa sistem bimbingan laporan Praktik Kerja Lapangan sudah sesuai dengan kebutuhan pengguna dan sangat layak digunakan.
\end{abstract}

This work is licensed under a Creative Commons Attribution-Share Alike 4.0

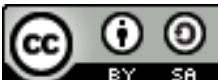

Sitasi Dokumen ini:

M. Khairi, "Web-Based Job Training Report Guidance System at SMKN 2 Kraksaan,” Buletin Ilmiah Sarjana Teknik Elektro, vol. 2, no. 3, pp. 153-162, 2020. DOI: 10.12928/biste.v2i3.3343 


\section{PENDAHULUAN}

Sekolah Menengah Kejuruan merupakan lembaga pendidikan yang berfungsi untuk membekali peserta didik dengan ilmu pengetahuan dan teknologi serta kecakapan profesi sesuai dengan kebutuhan masyarakat. Salah satu upaya untuk mencapai fungsi tersebut yaitu dengan penerapan pembelajaran sistem ganda, yaitu pembelajaran yang diselenggarakan di sekolah dan pembelajaran yang diselenggarakan di Dunia Usaha dan Dunia Industri (DU/DI) yang dinamakan Praktik Kerja Lapangan (PKL). Penyelenggaraan Praktek kerja Lapangan merupakan upaya yang dapat dilakukan SMK untuk tetap menghasilkan lulusan yang dapat bersaing di dunia usaha dan dunia industri (DU/DI) [1]. Salah satu kegiatan dalam pelaksanaan PKL adalah pembuatan laporan yang dibimbing oleh guru pembimbing sekolah yang format laporan sesuai dengan ketentuan sekolah. Laporan PKL berisi hasil kompilasi kegiatan pembelajaran yang dilakukan oleh siswa PKL di Institusi Pasangan/Industri [2].

Pandemik Coronavirus Disease 2019 (COVID-19) memberikan dampak pada sektor pendidikan yaitu dengan pemberlakuan pembelajaran di/dari rumah untuk mengurangi kontak fisik sebagai salah satu cara untuk memutuskan mata rantai penyebaran COVID-19 [3]. Dampak dari Kebijakan pemerintah juga memiiki pengaruh pada proses pembimbingan siswa PKL yang tidak dapat bertemu secara langsung pembimbing sehingga mempengaruhi proses pemahaman siswa dalam melakukan penulisan Laporan Praktik Kerja Lapangan. Berdasarkan fakta pengguna smartphone di kalangan siswa kelas XI sebesar 95\% dan terkoneksi ke dalam jaringan internet. sehingga salah satu langkah yang dilakukan oleh SMKN 2 Kraksaan untuk mengatasi masalah tersebut yaitu dengan melakukan pembimbingan menggunakan media sosial. Penggunaan media sosial belum efektif karena kebanyakan siswa mengalami permasalahan format dokumen laporan yang banyak dialami siswa bidang non Teknologi Informasi dan Komunikasi. Disisi lainnya ada ketidaksamaan versi software pengolah kata yang mengakibatkan perbedaan format penulisan dokumen laporan yang dikirim oleh siswa PKL dengan laporan yang diterima oleh pembimbing.

Berdasarkan fakta yang terjadi, maka diperlukan sebuah sistem yang dapat mengatasi permasalahan di atas, salah satu dengan membangun sebuah sistem pembimbingan laporan berbasiss web. Sistem berbasis web memudahkan interaksi antara pengguna aplikasi selama dalam jaringan internet [4] dan dapat diakses dimana pun dan kapan saja. Penelitian ini menggunakan model perangkat lunak waterfall, dimana tahapan-tahapan pengembangan perangkat lunak terstruktur dengan jelas dan tidak ada pengulangan [5]. Sistem ini dibangun menggunakan pemrograman server side PHP yang dapat melakukan pengelolaan dengan basisdata MySQL sehingga data tersimpan dengan baik dan aman [6]. Sistem yang diharapkan dapat mempermudah siswa dalam proses pembimbingan dan siswa dapat mengisi konten sub bab dari laporan PKL, sedangkan pemformatan penulisan dilakukan oleh sistem.

\section{METODE PENELITIAN}

Sistem yang baik harus dibangun dengan menggunakan tahapan-tahapan jelas agar dapat menghasilkan sistem yang sesuai dengan kebutuhan pengguna [7] Model waterfall merupakan model yang banyak digunakan untuk membangun perangkat lunak oleh kalangan akademisi maupun industri [8].

Tahapan-tahapan model Waterfall yang digunakan dalam membangun sistem bimbingan laporan praktik kerja lapangan seperti Gambar 1 [9].

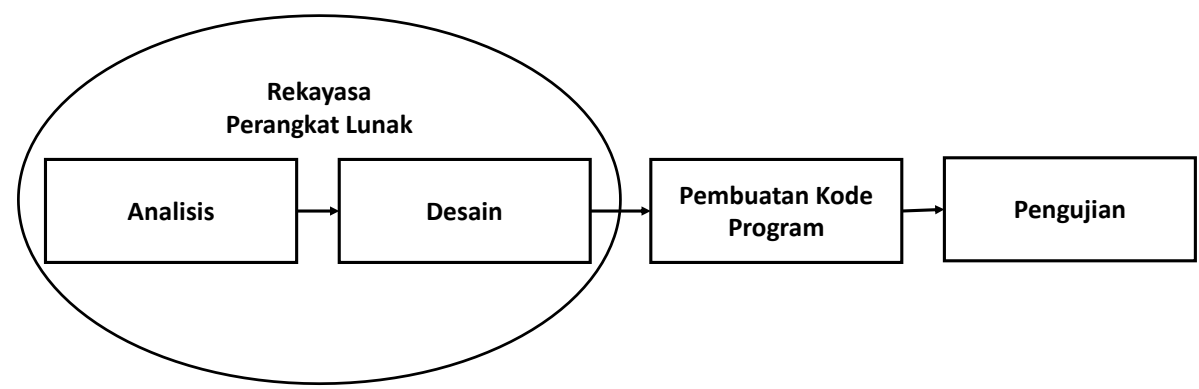

Gambar 1. Model Waterfall

1. Analisa

Pada tahapan ini, peneliti melakukan pengumpulan data dan penelusuran masalah sehingga dapat mengetahui kebutuhan sistem yang akan dibangun sesuai dengan kebutuhan fungsional pengguna.

2. Desain

Tahapan ini melakukan perencanaan dan penggambaran sistem yang akan dibangun sehingga dapat dipahami apa saja yang akan dikerjakan. Proses penggambaran sistem menggunakan alat perancangan sistem berupa Flowmap Diagram, Data Flow Diagram (DFD), dan Conceptual Data Model (CDM).

3. Pengkodean 
Tahapan pengkodean merupakan proses mengimplementasikan desain sistem yang dirancang menjadi perangkat lunak. Penelitian ini menggunakan Bahasa pemrograman PHP dan database MySQL.

4. Pengujian

Pengujian dilakukan untuk menemukan kesalahan pada perangkat lunak serta mengetahui kualitas perangkat lunak yang diuji. Untuk menguji perangkat lunak menggunakan metode back box testing yaitu menguji antar muka perangkat lunak tanpa memperhatikan struktur logis internal perangkat lunak [10]. Selain pengujian metode black box, juga diuji kelayakan perangkat lunak dengan menggunakan angket skala likert yaitu skala yang digunakan untuk mengukur perilaku individu meliputi pendapat, sikap, dan persepsi [11]. Langkah-langkah yang digunakan dalam pengujian sebagai berikut

a. Menentukan skor jawaban responden seperti pada Tabel 1.

Tabel 1. Skor Jawaban

\begin{tabular}{|l|l|}
\hline \multicolumn{1}{|c|}{ Jawaban } & Nilai \\
\hline Sangat Baik (SB) & 5 \\
\hline Baik (B) & 4 \\
\hline Cukup (C) & 3 \\
\hline Kurang (K) & 2 \\
\hline Sangat Kurang (SK) & 1 \\
\hline
\end{tabular}

b. Menghitung skor jawaban responden dilakukan menggunakan persamaan 1 [12]

$$
\text { skor perolehan }=\text { jumlah reponden } \times \text { nilai }
$$

c. Mengetahui persentase kelayakan sistem menggunakan persamaan 2 berikut:

$$
\text { Persentase Kelayakan }=\frac{\text { skor perolehan }}{\text { skor ideal }} \times 100 \%
$$

d. Interpretasi kelayakan sistem dapat dilihat pada Tabel 2.

Tabel 2. Hasil Interpretasi Skor [13]

\begin{tabular}{|c|c|c|}
\hline No & Persentase & Interpretasi \\
\hline 1 & $0 \%-25 \%$ & Kurang Layak \\
\hline 2 & $26 \%-50 \%$ & Cukup Layak \\
\hline 3 & $51 \%-75 \%$ & Layak \\
\hline 4 & $76 \%-100 \%$ & Sangat Layak \\
\hline
\end{tabular}

\section{HASIL DAN PEMBAHASAN}

Sistem bimbingan Praktik Kerja Lapangan dibangun dengan melakukan pemodelan perangkat lunak menggunakan tahapan model waterfall dengan tahapan berikut.

\subsection{Analisa}

Sistem bimbingan laporan PK memiliki tiga macam pengguna, yaitu sebagai administrator, pembimbing dan siswa. Ketiga pengguna memiliki peranan penting di dalam sistem sehingga harus didefinisikan kebutuhan pengguna.

1. Kebutuhan Administrator

Pengguna Administrator memiliki kebutuhan sebagai berikut

a. Mengelola data pengguna meliputi menambah data baru, mengubah data, dan menghapus data

b. Mengelola periode PKL

c. Mengelola dan menentukan pembimbing siswa PKL

d. Mengelola struktur laporan PKL, meliputi pengelolaan data bab dan subbab.

2. Kebutuhan Pembimbing

Pembimbing laporan PKL memiliki kebutuhan sebagai berikut:

a. Dapat melakukan login sesuai dengan user yang disediakan sistem

b. Melihat data bimbingan PKL

c. Melihat dan mereview konten laporan PKL siswa

d. Memberikan komentar kepada siswa PKL

3. Kebutuhan Siswa 
Adapun siswa PKL memiliki kebutuhan sebagai berikut:

a. Melakukan login sistem dengan user yang disediakan sistem

b. Mengisi konten bimbingan PKL

c. Melihat dan memberi jawaban komentar pembimbing

d. Mencetak laporan PKL

\subsection{Desain}

Setelah mengetahui kebutuhan sistem, dilanjutkan mendesain sistem dengan menggunakan alat perancangan sistem meliputi Flowmap, Data Flow Diagram, dan Entity Relationship Diagram. Berikut ini hasil desain dan perancangan system:

\section{Flowmap}

Sistem yang diusulkan dalam sistem bimbingan laporan PKL digambarkan pada Gambar 2. Siswa PKL mengisi konten laporan bimbingan, kemudian pembimbing me-review laporan tersebut dan memberikan komentar pada laporan yang ditulis siswa. Siswa dapat memperbaiki laporan apabila masih belum disetujui. Laporan dapat dicetak dan diberikan kepada Ketua Program Studi.

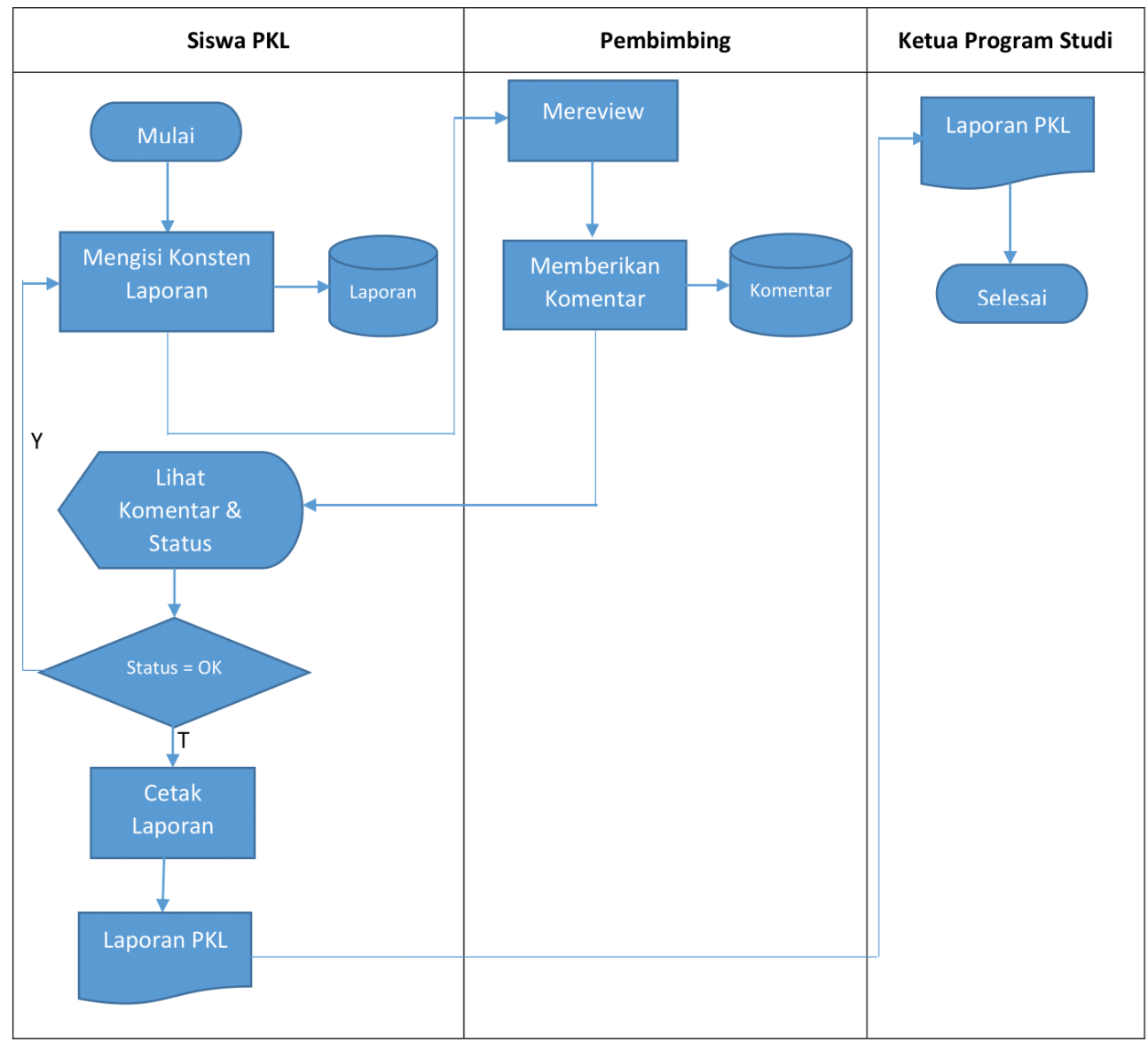

Gambar 2. Flowmap Bimbingan PKL

\section{Data Flow Diagram}

Aliran data pada sistem bimbingan laporan PKL digambarkan dengan menggunakan Data Flow Diagram (DFD). DFD merupakan suatu model yang menggambarkan asal data atau proses, tujuan data atau proses dan dimana data disimpan [14]. Secara garis besar digambarkan pada Gambar 3 menyesuaikan dengan alur sistem yang diusulkan. 


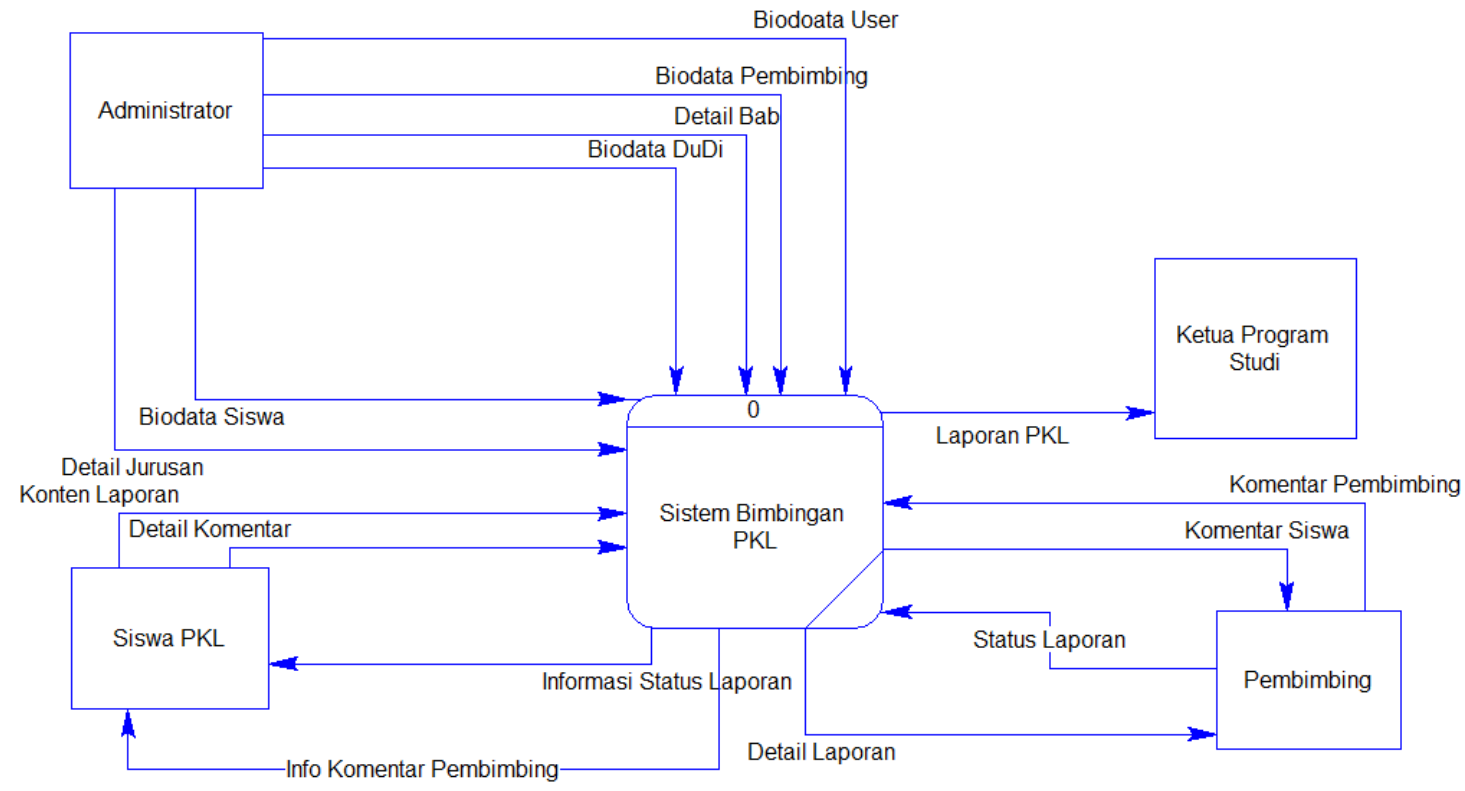

Gambar 3. Diagram Konteks Sistem

Gambar 4 menunjukkan proses lebih rinci diagram konteks disebut juga DFD level 1, dimana pada level ini data sudah diketahui tujuan penyimpan data (menghasilkan data storage).

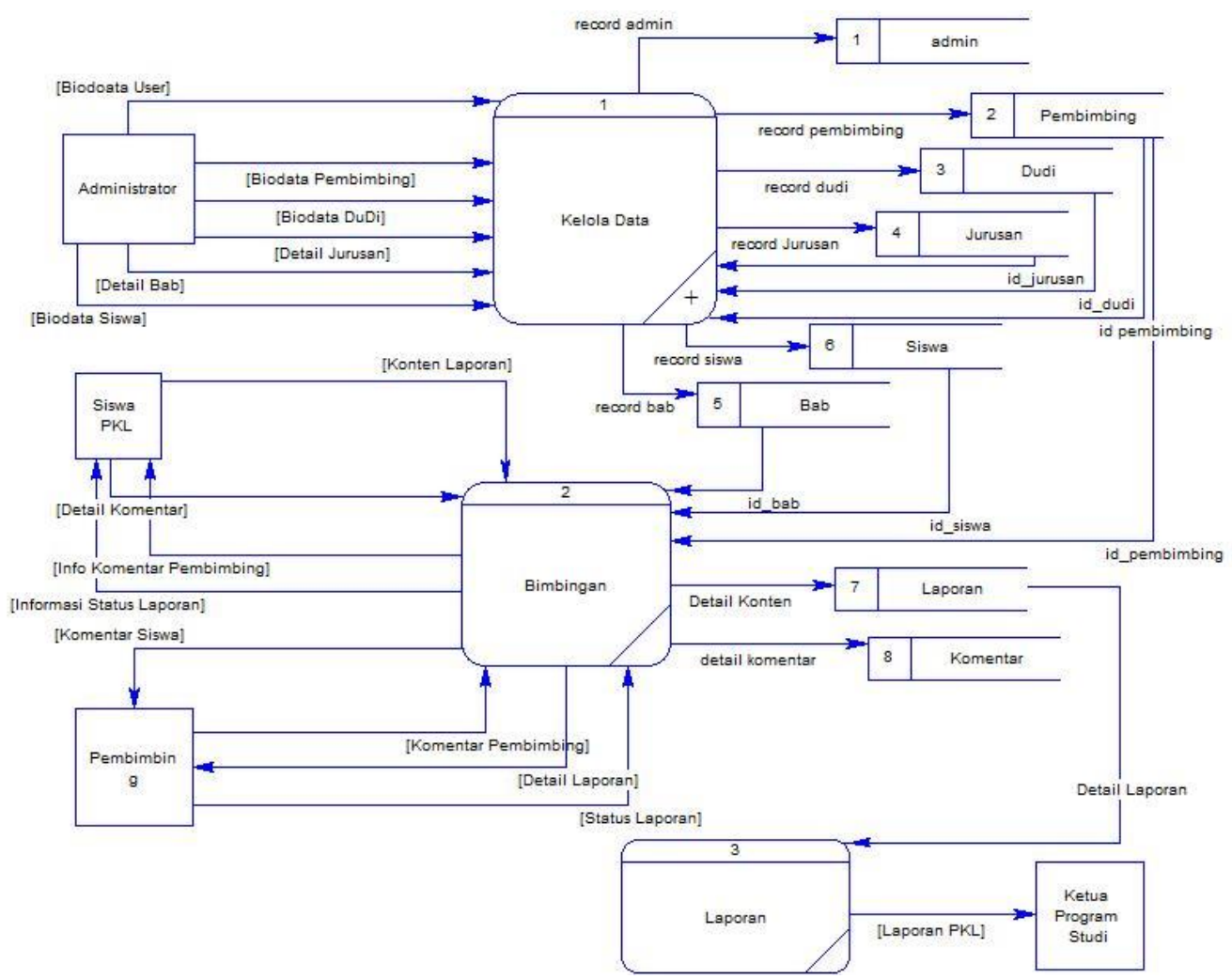

Gambar 4. DFD Level 1

\section{Entity Relationship Diagram}

Setelah menggambarkan data flow diagram, maka menghasil data storage yang dianalisis menjadi sebuah entitas basis data. Entitas ini dihubungkan sesuai dengan relasi data. Hubungan relasi antar entitas ini juga disebut entity relationship diagram yang digambarkan pada Gambar 5. 


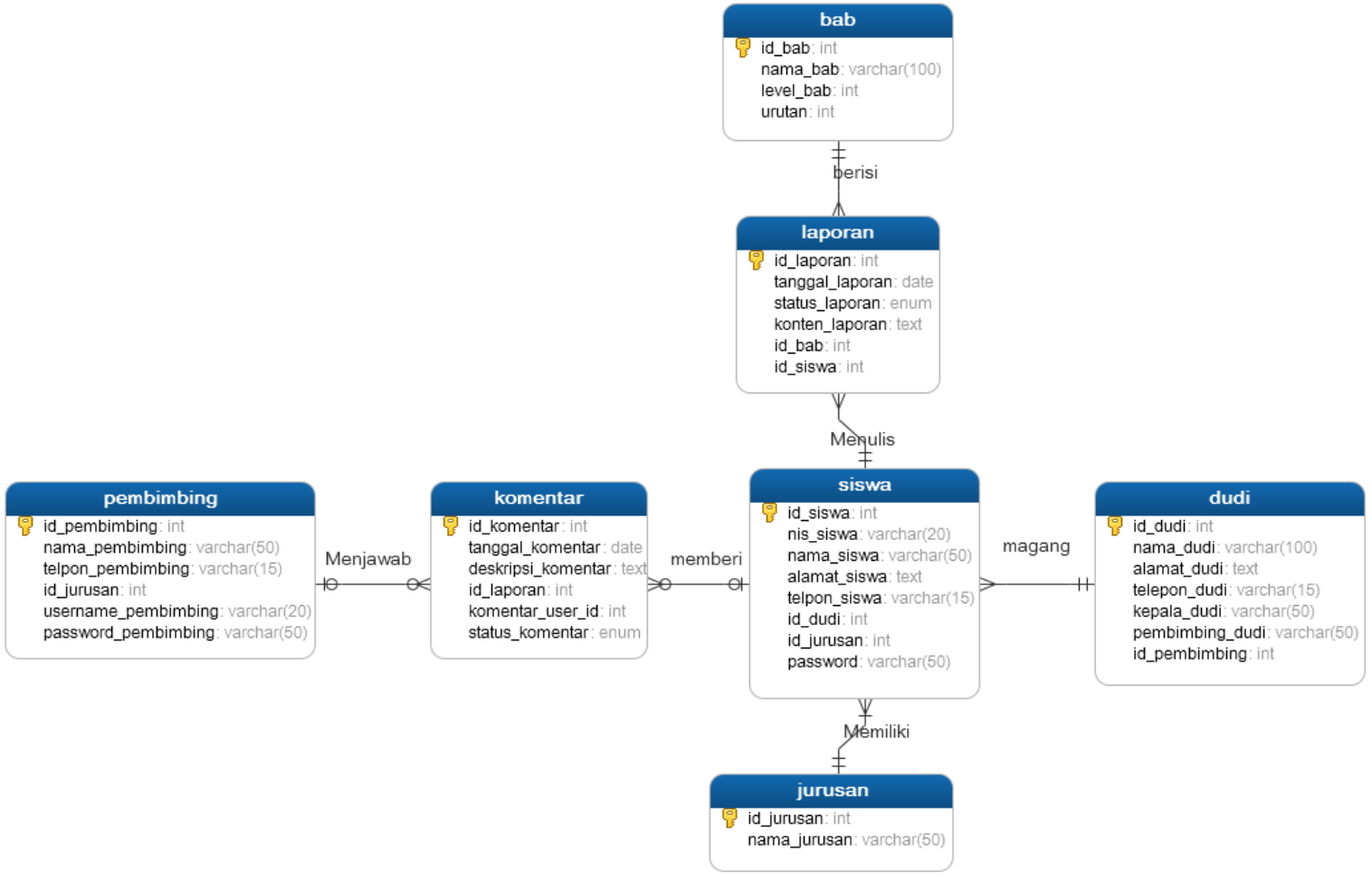

Gambar 5. Entity Relationship Diagram

\subsection{Pengkodean}

Sistem bimbingan laporan PKL dirancang untuk dapat diakses dimana pun dan kapan pun selama terkoneksi dengan jaringan internet, sehingga sistem ini dibangun dengan teknologi web menggunakan bahasa pemrograman server side PHP. Sistem bimbingan laporan PKL dapat dijalankan di komputer ataupun smartphone dengan mengakses menggunakan browser dengan tampilan awal aplikasi seperti pada Gambar 6.

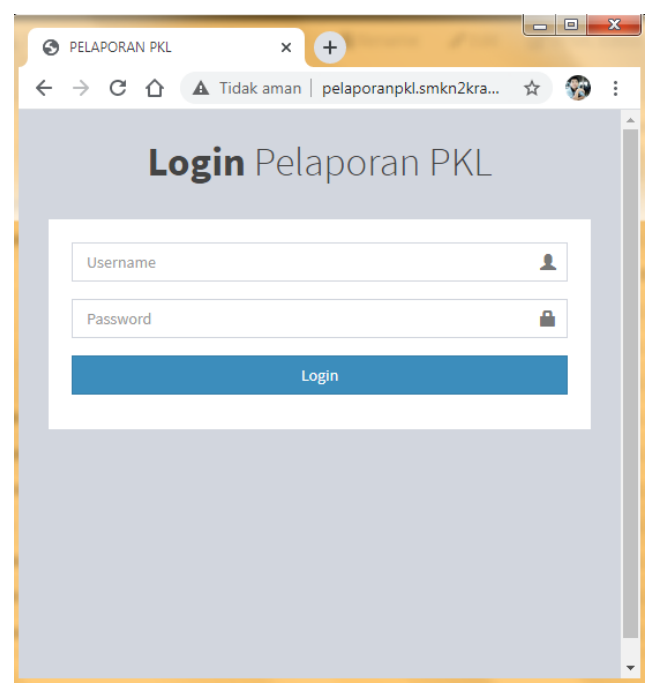

Gambar 6. Tampilan awal Sistem

Pengguna sistem dapat mengakses halaman menu utama sistem dengan memasukkan username dan password yang diberikan oleh admin, jika username dan password sesuai dengan data pengguna akan tampil halaman dashboard seperti pada Gambar 7. 


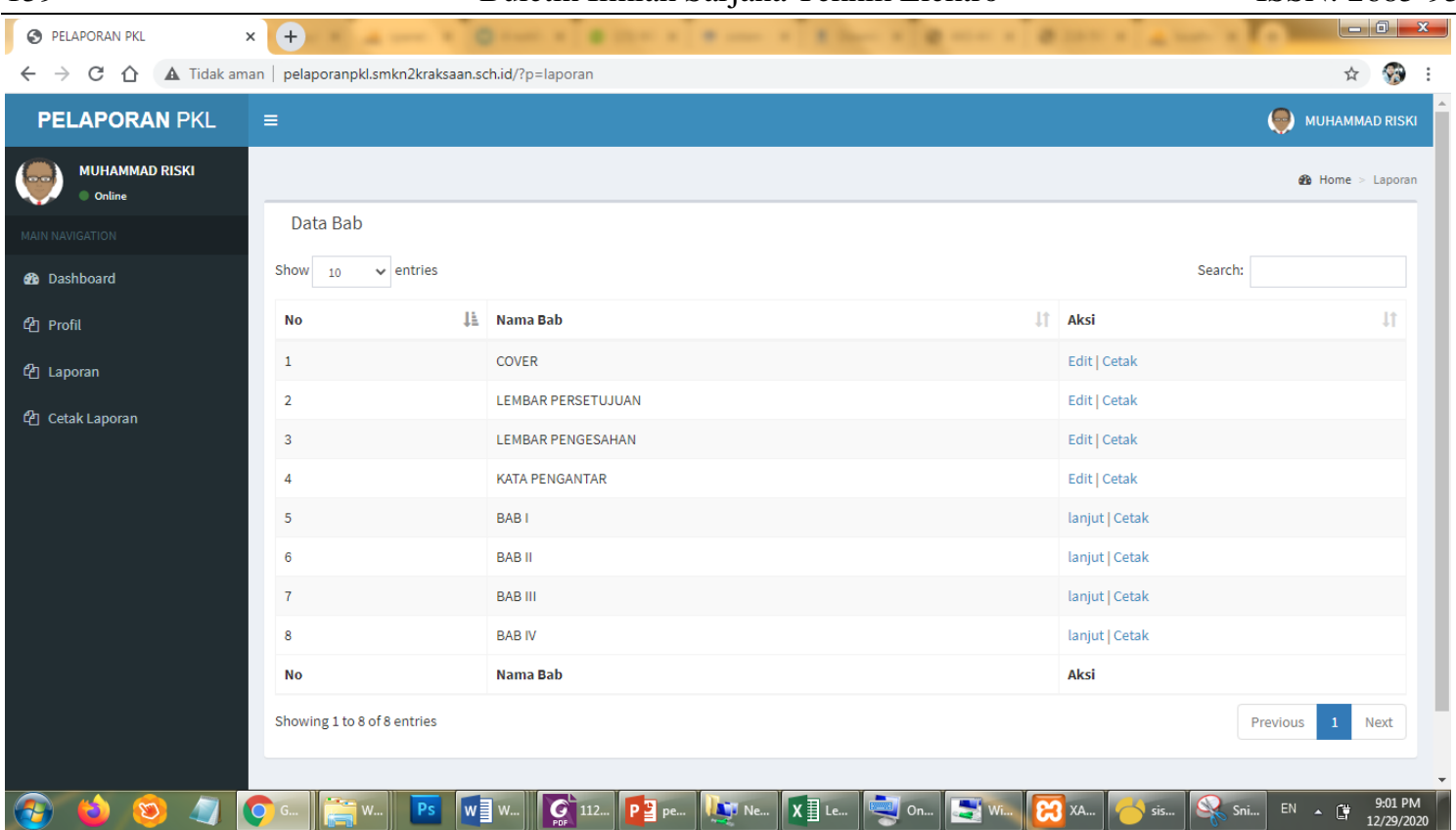

Gambar 7. Halaman Utama Sistem

Siswa dapat melakukan pengisian konten laporan dengan melakukan memilih link edit salah satu bab tau sub bab seperti pada Gambar 8.

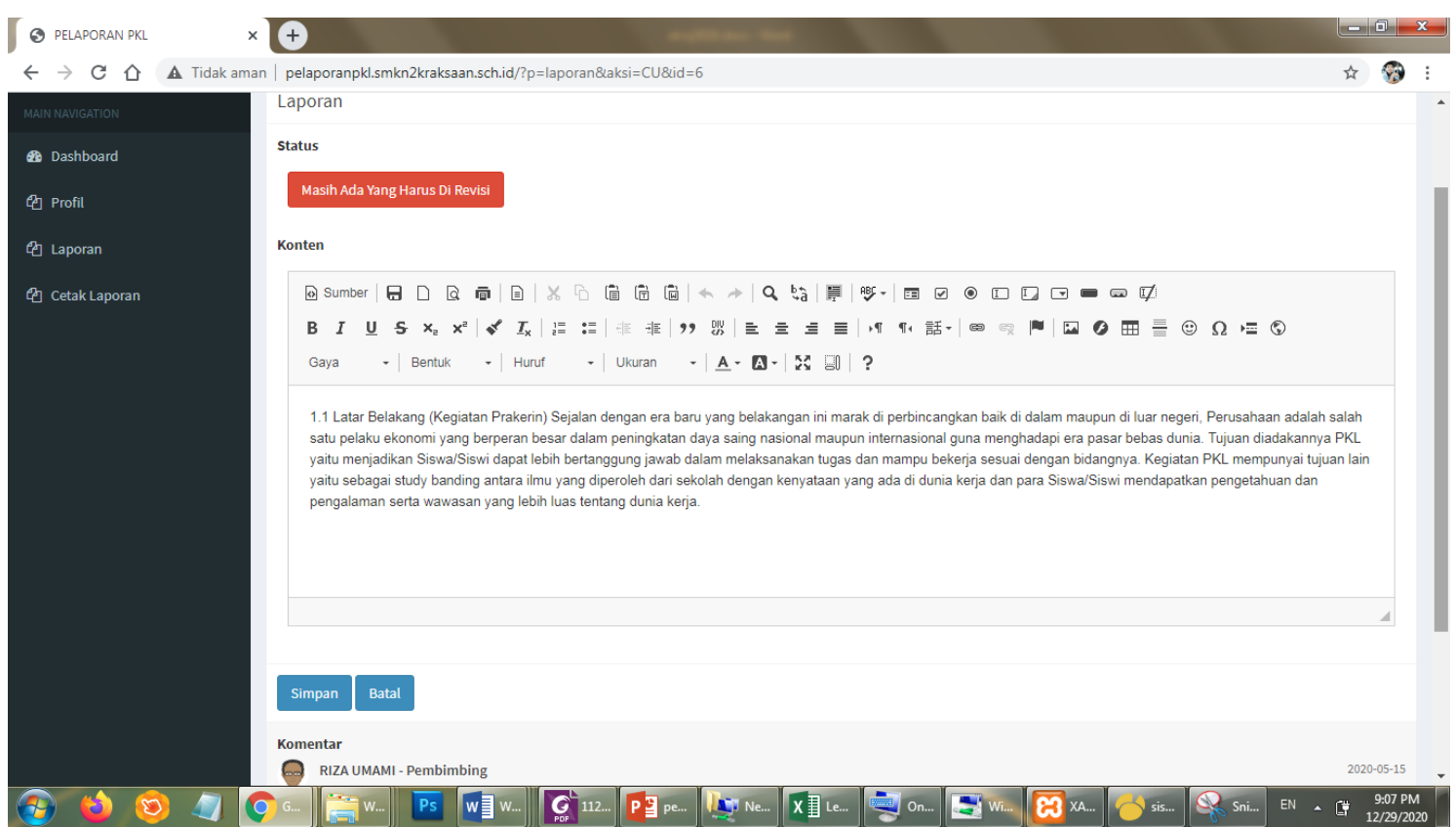

Gambar 8. Halaman Konten Laporan

Pada halaman di atas siswa dan pembimbing dapat berkomunikasi melalui komentar dan juga siswa dapat mengetahui status laporan yaitu perlu revisi, atau sudah ok. Jika laporan PKL sudah disetujui siswa dapat melakukan pencetakan dokumen laporan PKL dengan menekan link cetak sehingga tampil seperti pada Gambar 9. 


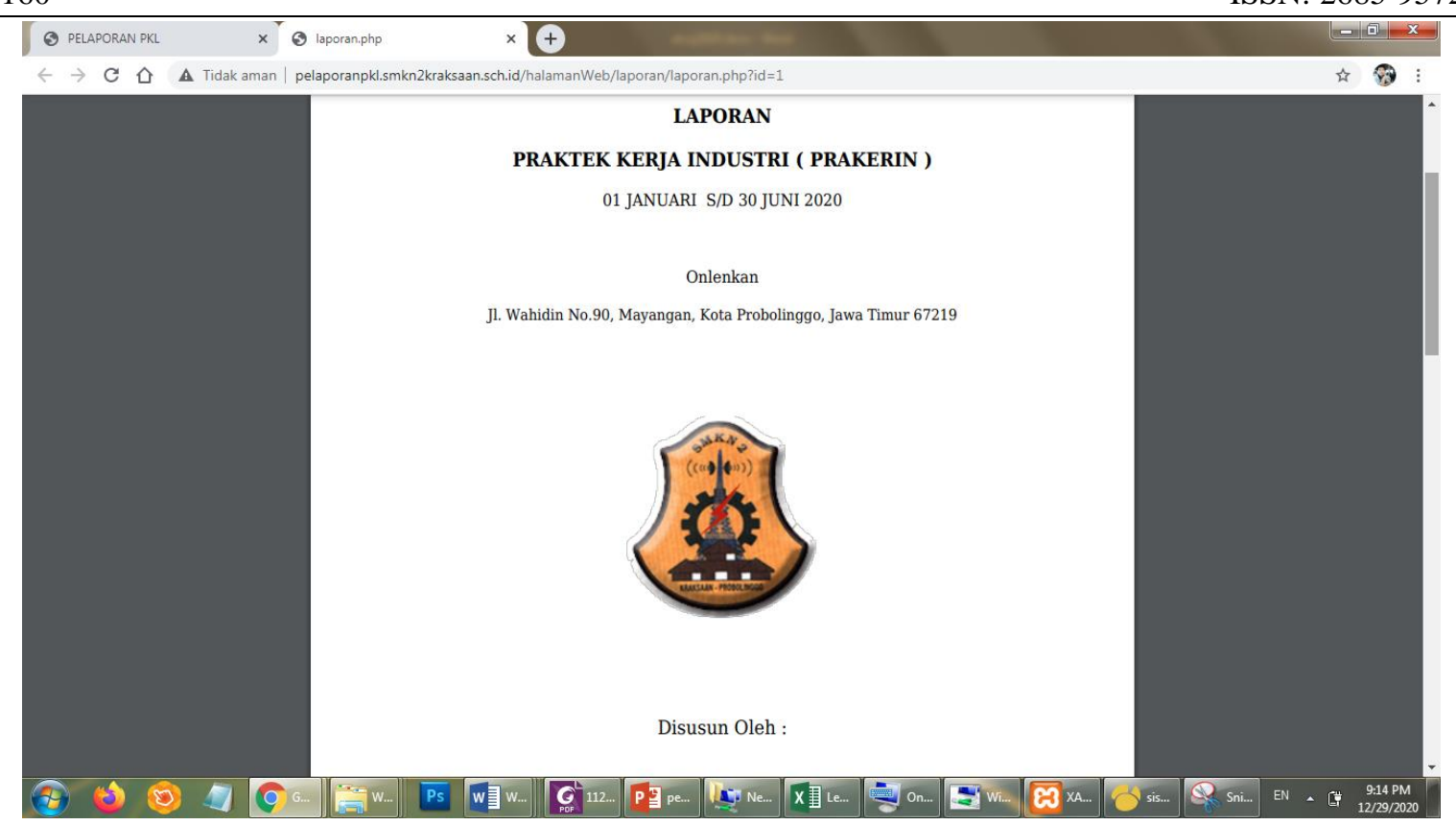

Gambar 9. Hasil Cetak Laporan

\subsection{Pengujian}

Pengujian dilakukan menggunakan dua metode yaitu pengujian black box dan angket. Pengujian black box dilakukan untuk menguji keluaran apakah sesuai dengan hasil yang diinginkan. Tabel 3 adalah hasil pengujian black box.

Tabel 3. Hasil Pengujian Black Box

\begin{tabular}{|c|c|c|c|}
\hline Modul & Skenario & Harapan & Hasil Pengujian \\
\hline \multirow[t]{2}{*}{ Login } & \begin{tabular}{llll} 
Memasukan & \multicolumn{2}{c}{ username } & dan \\
password sesuai data & di \\
database & & &
\end{tabular} & $\begin{array}{l}\text { Menampilkan halaman utama } \\
\text { sistem }\end{array}$ & Valid \\
\hline & $\begin{array}{l}\text { Memasukan username dan } \\
\text { password tidak sesuai denga } \\
\text { data }\end{array}$ & 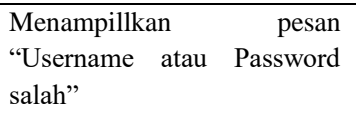 & Valid \\
\hline \multirow[t]{2}{*}{ Laporan } & $\begin{array}{l}\text { Memasukan konten berupa teks } \\
\text { dan gambar }\end{array}$ & $\begin{array}{lrr}\text { Teks dan gambar } & \text { dapat } \\
\text { disimpan di database } & \\
\end{array}$ & Valid \\
\hline & $\begin{array}{l}\text { Mengubah status bab laporan } \\
\text { PKL }\end{array}$ & $\begin{array}{l}\text { Menampilkan status warna } \\
\text { merah jika beluma disetujui, } \\
\text { warna hijau jika sudah } \\
\text { disetujui }\end{array}$ & Valid \\
\hline \multirow[t]{2}{*}{ Komentar } & Mengisi komentar & $\begin{array}{lll}\begin{array}{l}\text { Komentar } \\
\text { ditampikan }\end{array} & \text { tersimpan dan } \\
\end{array}$ & Valid \\
\hline & $\begin{array}{l}\text { Komentar kosong kemudian } \\
\text { tekan simpan }\end{array}$ & $\begin{array}{lll}\text { Menampilkan } & \text { pesan } \\
\text { "Komentar tidak } & \text { boleh } \\
\text { kosong" } & & \\
\end{array}$ & Valid \\
\hline Cetak Laporan & Klik link cetak laporan & $\begin{array}{l}\text { Menampilkan laporan dalam } \\
\text { bentuk file pdf }\end{array}$ & Valid \\
\hline
\end{tabular}

Pengujian selanjutnya dilakukan untuk melihat kelayakan sistem dengan menguji langsung kepada pengguna sehingga dapat melihat respon atau pendapat pengguna terhadap sistem. Angket disebarkan kepada siswa dengan mengambil sampel 10 siswa setiap kelas pada praktik kerja lapangan 2020 gelombang pertama sehingga jumlah responden keseluruhan berjumlah 70. Adapun hasil angket dapat dilihat dari Tabel 4. Dari rekapitulasi di atas dapat dihitung persentase kelayakan sebagai berikut

1. Mencari skor perolehan dengan mengalikan masing-masing jawaban responden dengan skor pada Tabel

1 sehingga

skor perolehan $=(183 \times 5)+(92 \times 4)+(40 \times 3)+\times(25 \times 2)+(10 \times 1)$

$$
=1463
$$


2. Mencari skor ideal sebagai

$$
\begin{aligned}
\text { Skor Ideal } & =5 \times 70 \times 5 \\
& =1750
\end{aligned}
$$

3. Berdasarkan persamaan 2, maka persentase kelayakan

$$
\begin{aligned}
\text { Persentase Kelayakan } & =\frac{1463}{1750} \times 100 \% \\
& =83,6 \%
\end{aligned}
$$

\begin{tabular}{|c|c|c|c|c|c|c|}
\hline \multirow{2}{*}{ NO } & \multirow{2}{*}{ Pernyataan } & \multicolumn{5}{|c|}{ Jawaban Responden } \\
\hline & & SB & B & $\mathbf{C}$ & $\mathbf{K}$ & SK \\
\hline 1 & Kemudahan dalam login user & 55 & 10 & 5 & 0 & 0 \\
\hline 2 & $\begin{array}{l}\text { Sistem memberikan kemudahan memasukkan } \\
\text { konten bimbingan laporan }\end{array}$ & 43 & 12 & 10 & 5 & 0 \\
\hline 3 & $\begin{array}{l}\text { Sistem memberikan kemudahan interaksi antara } \\
\text { siswa dan guru }\end{array}$ & 30 & 15 & 10 & 10 & 5 \\
\hline 4 & Sistem dapat diakses menggunakan smartphone & 15 & 30 & 10 & 10 & 5 \\
\hline 5 & Sistem memberikan kemudahan mencetak laporan & 40 & 25 & 5 & 0 & 0 \\
\hline & Total & 183 & 92 & 40 & 25 & 10 \\
\hline
\end{tabular}

Tabel 4. Hasil Rekap Angket

Nilai persentase kelayakan pada pengujian sistem ini sebesar 83,6 \% menunjukkan bahwa sistem bimbingan laporan praktik kerja lapangan berbasis web sangat layak sesuai hasil interpretasi pada tabel 2. Sistem bimbingan praktik kerja lapangan berbasis web memudahkan proses pembimbingan tanpa harus melakukan pengaturan format dokumen laporan..

\section{KESIMPULAN}

Sistem bimbingan praktik kerja lapangan berbasis web di SMKN 2 Kraksaan telah dirancang dan dibangun menggunakan teknologi berbasis web menggunakan bahasa pemrograman PHP dan database MySQL. Sistem bimbingan praktik kerja lapangan sudah sesuai dengan kebutuhan pengguna sistem, hal ini dilihat dari pengujian black box semua fitur valid. Berdasarkan respon pengguna melalui angket, sistem bimbingan praktik kerja lapangan sangat layak dengan persentase kelayakan 83,6\%.

\section{UCAPAN TERIMA KASIH}

Kami menyampaikan terima kasih yang sebesar-besarnya kepada editor dan reviewer yang telah berkenan menelaah, me-review dan memberikan masukan serta saran sehingga dapat memperbaiki kualitas dari penelitian. Semoga Allah membalasnya dengan balasan yang lebih baik.

\section{REFERENSI}

[1] Dikmenjur, Prakerin Sebagai Bagian dari Pendidikan Sistem Ganda, Jakarta: Depdikbud, 2016.

[2] A. N. Sirait, Peranan Dunia Usaha Dunia Industri dan Sekolah pada Praktek Kerja Lapangan Siswa Program Keahlian Tata Kecantikan Kulit SMK Negeri 27 Jakarta, Jakarta: Universitas Negeri Jakarta, 2016.

[3] P. Wahyono, H. Husamah and S. A. Budi, "Guru Profesional di Masa Pandemi COVID-19: Review Implementasi, Tantangan, dan Solusi Pembelajaran Daring," Jurnal Pendidikan Profesi Guru., vol. 1, no. 1, pp. 51-65,, 2020.

[4] M. R. Shofiyulloh, A. T. Wibowo and F. M. Amin, "Rancang Bangun Sistem Informasi Pelayanan Skripsi untuk Mendukung Layanan Akademik," Nusantara Journal of Computers and Its Applications., vol. 5, no. 1, pp. 8-15, 2020.

[5] C. D. R. Amirillah, S. Andriyana and Benrahman, "Perancangan Aplikasi Document Management System Berbasis Web Universitas Nasional dengan Metode Waterfall," Satuan Tulisan Riset dan Inovasi Teknologi, vol. 5, no. 1, 2020.

[6] J. Enterprise, HTML, PHP, dan MySQL untuk Pemula, Jakarta: Elex Media Komputindo, 2018.

[7] M. Mutazam, . L. D. Samsumar and D. Arwidiyarti, "Rancang Bangun Sistem Evaluasi KinerjaDosen Dalam Perkuliahan Untuk Meningkatkan Kualitas Perkuliahan," Jurnal Teknologi Informasi Dan Komunikasi, vol. 7, no. 1, pp. 74-87, 2018.

[8] S. V. Yulianto and A. P. Atmaja, "Rancang Bangun Sistem Informasi Kurikulum 2013 Tingkat Sekolah Dasar Berbasis Web dengan SDLC Waterfall," Jurnal Sisfo, vol. 7, no. 2, pp. 149-164, 2018.

[9] A. S. Rosa and M. Shalahuddin, Rekayasa Perangkat Lunak Terstruktur dan Berorientasi Objek, Bandung: Informatika Bandung, 2015.

[10] V. Frigustini, A. Erlansari and D. Andreswari, "Implementasi Algoritma Horspoolpada Aplikasi Kamus Bahasa Lintang -Indonesia Berbasis Android," Jurnal Rekursif, vol. 6, no. 1, 2018. 
[11] S. Bahrun, S. Alifah and S. Mulyono, "Rancang Bangun Sistem Informasi Survey Pemasaran dan Penjualan Berbasis Web," Jurnal Transistor Elektro dan Informatika, vol. 2, no. 2, pp. 81-88, 2017.

[12] Mufariya, Ilhamsyah and S. Rahmayuda, "Rancang Bangun Sistem Informasi Sumbangan Pembinaan Pendidikan (SPP) dengan Teknologi SMS Gateway," Jurnal Komputer dan Aplikasi, vol. 7, no. 2, pp. 19-28, 2019

[13] D. Yulistina and B. D. Dwi Arianti, "E-Katalog Sebagai Sistem Informasi Pemasaran Kopi Sapit Berbasis Web," EDUMATIC: Jurnal Pendidikan Informatika, vol. 2, no. 2, pp. 45-52, 2019.

[14] A. F. Zuhri, A. Ahmad, I. Parlina, R. Dewi and S. , "Sistem Informasi Data Rehabilitasi Narkoba Pada Badan Narkotika Nasional Kota (BNNK) Pematangsiantar," SAINTEKS 2020, pp. 255-260, 2020.

\section{BIOGRAFI PENULIS}

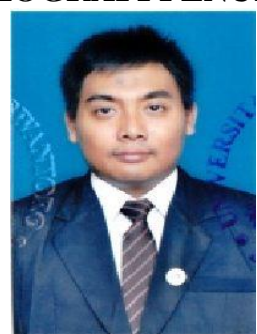

Matlubul Khairi

Penulis adalah Dosen Program Studi Teknik Informatika, Fakultas Teknik, Universitas Nurul Jadid. Berfokus pada Pemrograman Desktop dan Kecerdasan Komputer. 